\title{
Fate of Copper in Soils from Different Fertilizer Doses in Relation to Environmental Risk Assessment
}

\author{
Ewa Stanislawska-Glubiak*, Jolanta Korzeniowska \\ Institute of Soil Science and Plant Cultivation, State Research Institute, Department of Weed Science \\ and Soil Tillage Systems in Wrocław, Poland
}

Received: 22 August 2017

Accepted: 23 September 2017

\begin{abstract}
Total copper distribution in the soil profile was determined, depending on the type of soil and $\mathrm{Cu}$ dose, 5 years after the application of this element. Soil samples were taken from 5 layers to $50 \mathrm{~cm}$ depth from microplots filled with 3 types of soil that 5 years earlier had been treated with 5 doses of $\mathrm{Cu}$ : 4, 8 , 12 , and $16 \mathrm{~kg} \mathrm{ha}^{-1}$. There was an uneven distribution of $\mathrm{Cu}$ in the soil profile. In general the $\mathrm{Cu}$ decreased in the subsurface layers $(10-30 \mathrm{~cm})$ and increased in deeper layers $(30-50 \mathrm{~cm})$ in relation to the surface layer $(0-10 \mathrm{~cm})$. Using PCA analysis, both soils and doses of similar $\mathrm{Cu}$ distribution in the soil profile were pointed out. The distribution pattern in the sandy soil differed from the other two sandy loam soils. Additionally, for 4 and $8 \mathrm{~kg} \mathrm{ha}^{-1}$ doses, we recorded a similar $\mathrm{Cu}$ distribution as for the soil with natural $\mathrm{Cu}$ concentration. On the other hand, in the case of the doses of 12 and $16 \mathrm{~kg} \mathrm{ha}^{-1}$, there was a distinctly different pattern of distribution. The maximum dose of $\mathrm{Cu}$, which can be applied every 5 years, is $8 \mathrm{~kg} \mathrm{ha}^{-1}$ for the sandy soil with a low content of organic matter and $12 \mathrm{~kg} \mathrm{ha}^{-1}$ for sandy loam.
\end{abstract}

Keywords: copper, soil, doses, vertical distribution, environmental hazard

\section{Introduction}

In small quantities, $\mathrm{Cu}$ is absolutely necessary for plants to grow and develop. The deficiency of this element in soil leads to a decrease in crop yield and should be supplemented by fertilization [1-2]. In the case of a significant $\mathrm{Cu}$ deficit, soil fertilization is recommended, which compensates for this deficit for a few following years. As many as $40 \%$ of soils in Poland are deficient in $\mathrm{Cu}$ and should be fertilized when growing plants that are sensitive to the absence of this element [3].

*e-mail: e.glubiak@iung.wroclaw.pl
The recommended dose is 6-12 $\mathrm{kg}^{-1} \mathrm{~h}^{-1}$ once every few years, depending on plant species [4]. However, there are reports in the literature that an intensive use of $\mathrm{Cu}$ in agricultural practices can lead to soil contamination. For example, the use of $\mathrm{Cu}$-based fungicides has led to an excessive accumulation of $\mathrm{Cu}$ in soils in Australian [5] and French vineyards [6], coffee fields in Tanzania [7], and apple orchards in Taiwan [8]. Similarly, using soil fertilization of wheat with $\mathrm{Cu}$ for 17 years in Shaanxi Province, China significantly increased its concentration in the top layer of the soil [9]. Excessive accumulation and leaching of $\mathrm{Cu}$ from agricultural soils can contaminate groundwater and pose a risk to humans and animals through the food chain. Cu toxicity and transport deep into the soil profile is closely related to its solubility [10]. 
$\mathrm{Cu}$ of natural origin shows a rather low mobility in the soil. In general, it forms insoluble complexes with organic matter and mineral soil fractions, and its content is highest in the several centimeters of topsoil [11]. The solubility of $\mathrm{Cu}$ involves the formation of its mobile species and depends on many soil factors such as $\mathrm{pH}$, oxidation, and reduction potential, the amount and type of organic matter, the texture of the soil, temperature, and humidity. High mobility in the soil is characteristic for $\mathrm{Cu}$ complexes with dissolved organic carbon (DOC). More intensive movement of $\mathrm{Cu}$ by the soil profile can be expected in soils with higher DOC compared to the soils with its lower content [12].

$\mathrm{Cu}$ of anthropogenic origin acts differently than the natural one. $\mathrm{Cu}$ fertilizers contain soluble, highly mobile $\mathrm{Cu}$ that can migrate deep into the soil profile. Over time, $\mathrm{Cu}$ transforms into less mobile compounds [13]. The effectiveness of this process depends on the sorption capacity of the soil. Soils that are more compact and rich in organic matter are able to fix more $\mathrm{Cu}$ [14].

Although determining the fertilization requirements involves assessing the so-called available $\mathrm{Cu}$ in the soil [15-17], in order to estimate the contamination, determining total $\mathrm{Cu}$ in aqua regia is still used in many countries. The limits for total $\mathrm{Cu}$ apply generally to the topsoil and vary depending on the country. For example, in the Netherlands "remediation intervention value" is 190 $\mathrm{mg} \mathrm{kg}^{-1}$ for $10 \%$ of organic matter and $25 \%$ of clay [18]. In Poland, "admissible concentration" oscillates between 100 and $300 \mathrm{mg} \mathrm{kg}^{-1} \mathrm{Cu}$ depending on the $\mathrm{pH}$ and soil texture [19].

Many authors describe the mobility and vertical distribution of heavy metals, including $\mathrm{Cu}$, in soils fertilized with sediment sewage sludge [20-22] contaminated by industry [23-25] or as a result of the use of Cu-based fungicides $[5,7-8]$. There is no information about the transport of $\mathrm{Cu}$ into the soil profile when applied in the form of fertilizers - especially in relation to the dose.

The aim of our study was to examine the vertical distribution of $\mathrm{Cu}$ in the soil a few years after the application of $\mathrm{Cu}$ sulphate in the aspect of a potential threat to groundwater.

\section{Experimental Procedures}

In autumn 2016 we collected soil samples from microplots located in Jelcz-Laskowice in Lower Silesia, Poland $\left(51^{\circ} 01^{\prime} \mathrm{N}, 17^{\circ} 18^{\prime} \mathrm{E}\right)$. In earlier years, these microplots were used for an experiment with the fertilization of winter wheat with $\mathrm{Cu}$. Five years before sampling, a concrete-framed microplot with a surface area of $1 \mathrm{~m}^{2}$ and a depth of $1 \mathrm{~m}$ (without bottoms) were filled with 3 soils and treated with different $\mathrm{Cu}$ doses. All 3 soils belonged to the Luvisols type, the most common type of soil in both Lower Silesia and across Poland [26].

Five doses of $\mathrm{Cu}$ were applied in the form of $\mathrm{CuSO}_{4}$ x $5 \mathrm{H}_{2} \mathrm{O}: \mathrm{Cu}_{0}-$ control (without $\mathrm{Cu}$ ), $\mathrm{Cu}_{1}-0.4, \mathrm{Cu}_{2}-0.8$, $\mathrm{Cu}_{3}-1.2$, and $\mathrm{Cu}_{4}-1.6 \mathrm{~g} \mathrm{~m}^{2} \mathrm{Cu}$. Cu sulphate dissolved in water was applied to the microplots with a hand-held watering can and then thoroughly mixed with the soil.

The microplots were located under the open sky, where the soil was exposed to the weather. Annual rainfall totals and annual average temperatures for the period from fertilization to soil sampling are shown in Table 1. In 2012-2015, winter wheat was cultivated on the microplots, while in 2016 no plant cover was used.

Soil samples were collected at the beginning of November 2016 from the layers of $0-10,10-20,20-$ $30,30-40$, and $40-50 \mathrm{~cm}$ with a $21 \mathrm{~mm}$ steel core tube. Five random cores were collected from each plot. Each sample was created by mixing five soil cores. In total, we collected 300 samples ( 3 soils x $5 \mathrm{Cu}$ doses x 5 layers $\mathrm{x}$ 4 replicates). All samples were air-dried, sieved through a $2 \mathrm{~mm}$ diameter, and stored in plastic boxes at room temperature.

Soil samples were analyzed for $\mathrm{Cu}$ concentration in aqua regia. After the digestion, $\mathrm{Cu}$ was determined using the FAAS method. In addition, soil $\mathrm{pH}$ was determined potentiometrically in $1 \mathrm{~mol} \mathrm{KCl} \mathrm{dm}{ }^{-3}$ (ISO10390: 2005), total organic carbon (TOC) by Tiurin method using potassium dichromate (PN-ISO14235:2003), and texture by the aerometric method (PN-R-04033:1998). The accuracy of the method was verified by reference material CRM028-50G trace metals-sandy loam 11 (Sigma-Aldrich RTC) with a total $\mathrm{Cu}$ content of $8.51 \pm 0.602 \mathrm{mg} \mathrm{kg}^{-1}$. All chemical analyses were done by the Central Laboratory of the Institute of Soil Science and Plant Cultivation State Research Institute, certified by the Polish Centre of Accreditation according to PN-EN ISO/IEC 17517025 (certificate No. AB 339).

The results of $\mathrm{Cu}$ concentration in the soil were given as the means from 4 replications. Calculations of ANOVA were performed with Statgraphics Centurion XV software (StatPoint, Inc.). Statistical significance was determined using Tukey's test $(\mathrm{P}<0.05)$. Principal component analysis (PCA) was perform using Statistica 10.0 software (StatSoft, Inc.).

\section{Results and Discussion}

\section{Physicochemical Properties of Soils}

Of the three soils used for our study, soil A was the least compact, with its texture changing with depth (Table 2). In the upper layers of soil A, there was a sand

Table 1. Total annual precipitation and average temperature in the region of the Experimental Station in Jelcz-Laskowice.

\begin{tabular}{|c|c|c|c|c|c|c|}
\hline Year & 2012 & 2013 & 2014 & 2015 & 2016 & $\begin{array}{c}1961- \\
2010\end{array}$ \\
\hline $\begin{array}{c}\text { Precipitation } \\
(\mathrm{mm})\end{array}$ & 579 & 670 & 598 & 346 & 526 & 565 \\
\hline $\begin{array}{c}\text { Temperature } \\
\left(\mathrm{C}^{\circ}\right)\end{array}$ & 8.9 & 8.7 & 10.1 & 10.5 & 9.8 & 8.7 \\
\hline
\end{tabular}


Table 2. Characteristics of the experimental soils.

\begin{tabular}{|c|c|c|c|c|c|c|c|c|}
\hline \multicolumn{9}{|c|}{ Soil fraction (mm) } \\
\hline \multirow{2}{*}{ Soil } & \multirow{2}{*}{$\begin{array}{l}\text { Depth } \\
\mathrm{cm}\end{array}$} & \multirow{2}{*}{$\mathrm{pH}$} & \multirow{2}{*}{$\begin{array}{c}\text { TOC } \\
\%\end{array}$} & $2.0-0.05$ & $0.05-0.02$ & $0.02-0.002$ & $<0.002$ & \multirow{2}{*}{ Texture } \\
\hline & & & & \multicolumn{4}{|c|}{$\%$} & \\
\hline \multirow{6}{*}{ A } & $0-10$ & 5.8 & 0.60 & 87 & 6 & 5 & 1 & S \\
\hline & $0-20$ & 5.3 & 0.60 & 86 & 7 & 6 & 1 & S \\
\hline & $20-30$ & 5.5 & 0.51 & 80 & 8 & 10 & 2 & LS \\
\hline & $30-40$ & 5.7 & 0.32 & 65 & 11 & 20 & 4 & SL \\
\hline & $40-50$ & 6.0 & 0.30 & 68 & 11 & 17 & 3 & SL \\
\hline & Average & 5.7 & 0.46 & 77 & 9 & 12 & 2 & \\
\hline \multirow{6}{*}{$\mathrm{B}$} & $0-10$ & 5.5 & 0.86 & 68 & 11 & 18 & 3 & SL \\
\hline & $0-20$ & 5.5 & 0.65 & 70 & 10 & 16 & 3 & SL \\
\hline & $20-30$ & 5.5 & 0.74 & 71 & 10 & 16 & 3 & SL \\
\hline & $30-40$ & 5.5 & 0.40 & 70 & 8 & 18 & 4 & SL \\
\hline & $40-50$ & 5.9 & 0.39 & 70 & 10 & 16 & 3 & SL \\
\hline & Average & 5.6 & 0.61 & 70 & 10 & 17 & 4 & \\
\hline \multirow{6}{*}{$\mathrm{C}$} & $0-10$ & 5.5 & 1.12 & 69 & 11 & 16 & 3 & SL \\
\hline & $0-20$ & 5.4 & 1.00 & 68 & 12 & 17 & 3 & SL \\
\hline & $20-30$ & 5.6 & 0.75 & 68 & 10 & 18 & 4 & SL \\
\hline & $30-40$ & 6.0 & 0.63 & 67 & 9 & 19 & 5 & SL \\
\hline & $40-50$ & 6.1 & 0.48 & 67 & 10 & 19 & 4 & SL \\
\hline & Average & 5.7 & 0.79 & 68 & 11 & 18 & 4 & \\
\hline
\end{tabular}

S-sand, LS-loamy sand, SL-sandy loam

that then changed into loamy sand, and deeper into the sandy loam. At the same time, the TOC decreased from $0.60 \%$ to $0.30 \%$, respectively. Soil $\mathrm{pH}$ varied in the range of 5.3-6.0, depending on the soil layer. The lowest value of this parameter was recorded in the layer of $10-20 \mathrm{~cm}$, while in the deeper layers $\mathrm{pH}$ increased.

Soils B and C were very similar in terms of texture. The entire tested profile of these soils $(0-50 \mathrm{~cm})$ was sandy loam. However, these soils differed in TOC distribution and soil $\mathrm{pH}$. Soil B contained 0.86-0.39\% of TOC, which decreased with depth, but there was a clear difference between $0-30 \mathrm{~cm}$ and $30-50 \mathrm{~cm}$. The average TOC for these two layers was $0.75 \%$ and $0.40 \%$, respectively. On the other hand, soil $\mathrm{pH}$ in the layers down to the depth of $40 \mathrm{~cm}$ was equal to 5.5 while deeper it rose to 5.9 .

In soil $\mathrm{C}$, the pattern of TOC distribution in the soil profile was different from that in soil B. It systematically decreased in the following layers ranging 1.12-0.48\%. Soil $\mathrm{pH}$ increased together with depth, from 5.5 to 6.1 .

Considering the values of soil parameters throughout the entire soil profile $(0-50 \mathrm{~cm})$, it should be noted that the soils did not differ in $\mathrm{pH}$, but there were some differences in TOC and silt content.

\section{Concentration and Vertical Distribution of $\mathrm{Cu}$}

The distribution and migration of metals in the soil is affected by soil texture, soil layer, the origin of the metal (anthropogenic or natural), and the total concentration of the metal $[24,28]$. In our studies, the $\mathrm{Cu}$ concentration found in soil 5 years after its application depended on the $\mathrm{Cu}$ dose and soil type (Table 3 ). The average $\mathrm{Cu}$ concentration in the soil profile to $50 \mathrm{~cm}$ depth on the treatments with natural $\mathrm{Cu}\left(\mathrm{Cu}_{0}\right)$ and ones fertilized with the lowest dose of this element $\left(\mathrm{Cu}_{1}\right)$ ranged from 6.2 to $8.6 \mathrm{~kg}^{-1}$. In the treatments fertilized with higher doses $\left(\mathrm{Cu}_{2}-\mathrm{Cu}_{4}\right)$, we recorded from 7.8 to $15.7 \mathrm{mg} \mathrm{kg}^{-1} \mathrm{Cu}$. element. These concentrations, even after the application of the highest $\mathrm{Cu}$ dose, were many times lower than the admissible limits for soil contamination with $\mathrm{Cu}$ (Table 3).

In soils $\mathrm{B}$ and $\mathrm{C}$ that were not fertilized with $\mathrm{Cu}$ $\left(\mathrm{Cu}_{0}\right)$, the concentration of this element was distributed relatively evenly in the soil profile layers, whereas in soil A it increased together with depth (Fig. 1, Table 4). Other authors reported that in the soils with natural $\mathrm{Cu}$, its concentration in sandy soils decreased down the depth of the profile, while in more compact soils it increased together with an increasing clay content [5]. 
Table 3. $\mathrm{Cu}$ concentrations in soil profile depending on the $\mathrm{Cu}$ dose after 5 years from its application (average over 5 layers).

\begin{tabular}{|c|c|c|c|}
\hline \multirow{2}{*}{ Dose } & \multicolumn{3}{|c|}{ Soil } \\
\cline { 2 - 4 } & $\mathrm{A}$ & $\mathrm{B}$ & $\mathrm{C}$ \\
\cline { 2 - 4 } & \multicolumn{3}{|c|}{$\mathrm{mg} \mathrm{kg}^{-1}$} \\
\hline $\mathrm{Cu} 0$ & $6.2 \mathrm{a}$ & $8.6 \mathrm{a}$ & $7.6 \mathrm{a}$ \\
\hline $\mathrm{Cu} 1$ & $6.6 \mathrm{a}$ & $8.4 \mathrm{a}$ & $8.5 \mathrm{ab}$ \\
\hline $\mathrm{Cu} 2$ & $7.8 \mathrm{~b}$ & $10.1 \mathrm{~b}$ & $8.9 \mathrm{~b}$ \\
\hline $\mathrm{Cu} 3$ & $10.7 \mathrm{c}$ & $11.5 \mathrm{c}$ & $13.2 \mathrm{c}$ \\
\hline $\mathrm{Cu} 4$ & $15.7 \mathrm{~d}$ & $14.8 \mathrm{~d}$ & $14.4 \mathrm{~d}$ \\
\hline $\mathrm{Average}$ & 9.4 & 10.7 & 10.5 \\
\hline$*$ & 100 & 100 & 100 \\
\hline$* *$ & 30 & 30 & 30 \\
\hline
\end{tabular}

*Admissible $\mathrm{Cu}$ concentration according Regulation of the Minister of the Environment [19]; **first level of $\mathrm{Cu}$ contamination (increased content) according Kabata-Pendias et al. [27]; the same letters for each soil indicate the lack of significant differences according to Tukey's test $(\mathrm{P}<0.05)$

In our study, in the soil treated with $\mathrm{Cu}\left(\mathrm{Cu}_{1}-\mathrm{Cu}_{4}\right)$, vertical distribution of this element after 5 years from application was different than in the soil with its natural content. The relations among individual soil layers in terms of $\mathrm{Cu}$ concentration were different in each soil and for each level of $\mathrm{Cu}$ fertilization.

We found generally less $\mathrm{Cu}$ in the subsurface soils $(10-20$ and $20-30 \mathrm{~cm})$ than in the surface soil $(0-10 \mathrm{~cm})$. This is confirmed by the results of Pietrzak and McPhail (2004), who recorded the depletion of $\mathrm{Cu}$ in the $10-20 \mathrm{~cm}$ layer (or even deeper than $25 \mathrm{~cm}$ ) compared to the surface layer. In our studies, the decrease of $\mathrm{Cu}$ in the subsurface layers was greatest in soil A, amounting to $40 \%$, while in soils B and C it did not exceed $21 \%$, whereas the impact of dose on the level of the decrease was uneven. In contrast, in deeper layers (30-40 and 40-50 cm), we observed both the decrease and increase in $\mathrm{Cu}$ concentrations in relation to the layer of $0-10 \mathrm{~cm}$. This increase was found in soil A for $\mathrm{Cu}_{3}$ and $\mathrm{Cu}_{4}(16-26 \%)$, and in soil $\mathrm{C}$ for $\mathrm{Cu}_{1}$ and $\mathrm{Cu}_{4}(10-23 \%)$. In soil $\mathrm{B}$, however, the increase of $\mathrm{Cu}$ concentration in relation to the layer of $0-10 \mathrm{~cm}$ was found only at a depth of $40-50 \mathrm{~cm}$ for $\mathrm{Cu}_{3}$ and $\mathrm{Cu}_{4}(11 \%$ and $46 \%$, respectively). Li et al. (2005), in the soil contaminated anthropogenically, found an uneven distribution of $\mathrm{Cu}$ in the soil profile, decreasing from the surface to the deeper layers, whereas the differences between the layers and the correlation between them in the content of $\mathrm{Cu}$ were significant.

An uneven distribution of total $\mathrm{Cu}$ among the soil layers is probably connected with a different $\mathrm{Cu}$ mobility and its movement to the deeper layers, or with $\mathrm{Cu}$ immobilization. According to Pietrzak and McPhail (2004), in soils not contaminated with $\mathrm{Cu}$, this element occurs mainly in less mobile forms (residual fraction + oxides of $\mathrm{Fe}$ and
Soil A

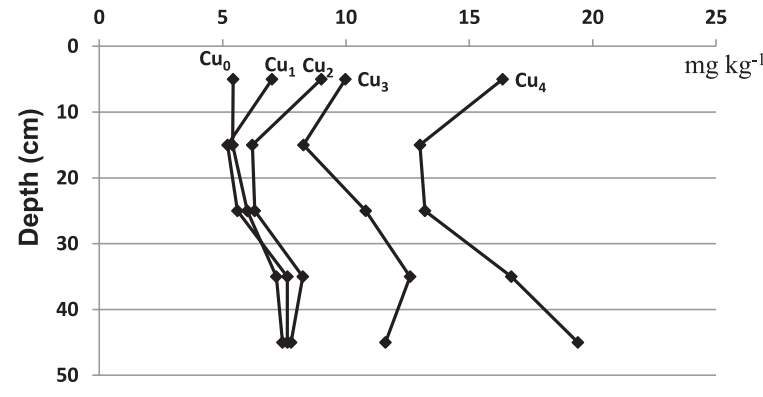

Soil B

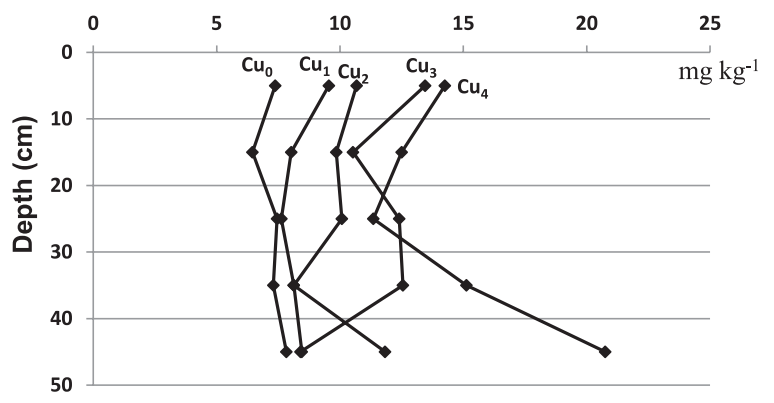

Soil C

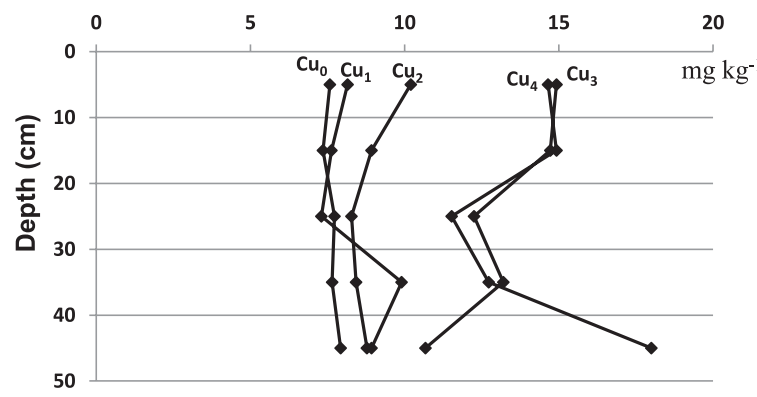

Fig. 1. Vertical distribution of $\mathrm{Cu}$ in soil profiles after 5 years from $\mathrm{Cu}$ application; $\mathrm{Cu}_{0}-$ control without $\mathrm{Cu}$ fertilization, $\mathrm{Cu}_{1}-0.4 \mathrm{~g} \mathrm{~m}^{-2}, \mathrm{Cu}_{2}-0.8 \mathrm{~g} \mathrm{~m}^{-2}, \mathrm{Cu}_{3}-1.2 \mathrm{~g} \mathrm{~m}^{-2}$, and $\mathrm{Cu}_{4}-1.6 \mathrm{~g} \mathrm{~m}^{-2}$.

$\mathrm{Al}$ ), while potentially available $\mathrm{Cu}$ constitutes only about $10 \%$ of total $\mathrm{Cu}$ in the soil profile. Antonkiewicz and Pelka [29] showed that in the uncontaminated silt loam, residual fraction constituted $38 \%$ of total $\mathrm{Cu}$. In the soils uncontaminated with $\mathrm{Cu}$, however, Kabala and Singh [24], in the case of sandy soil, found a low percentage of residual fraction in the surface and subsurface layers, which was a result of poor soil sorption capacity of this soil. In the silty and clay-loamy soils, the residual fraction in the subsurface layer was, respectively, 88 and $97 \%$ of total $\mathrm{Cu}$.

Fertilizing the soil with $\mathrm{Cu}$ as well as using $\mathrm{Cu}$ containing fungicides can pose a threat to the environment. Xiaorong et al. [9] showed that $\mathrm{Cu}$ soil fertilization for many years caused the accumulation of this element in the surface layer of the soil and its transportation deep down the soil profile. Mobile $\mathrm{Cu}$ forms moved even deeper than to a depth of $400 \mathrm{~cm}$.

The most mobile fractions are exchangeable $\mathrm{Cu}, \mathrm{Cu}$ weakly bound with organic matter, and $\mathrm{Cu}$ in carbonate 
Table 4. Cu concentrations in soil layers expressed as a percentage of $\mathrm{Cu}$ concentrations in the surface layer $(0-10 \mathrm{~cm})$.

\begin{tabular}{|c|c|c|c|c|c|c|}
\hline \multirow{2}{*}{ Soil } & \multirow{2}{*}{$\begin{array}{c}\text { Depth } \\
\mathrm{cm}\end{array}$} & $\mathrm{Cu}_{0}$ & $\mathrm{Cu}_{1}$ & $\mathrm{Cu}_{2}$ & $\mathrm{Cu}_{3}$ & $\mathrm{Cu}_{4}$ \\
\hline & & \multicolumn{5}{|c|}{$\%$} \\
\hline \multirow{5}{*}{ A } & $0-10$ & 100 & 100 & 100 & 100 & 100 \\
\hline & $10-20$ & 100 & 74 & 60 & 83 & 79 \\
\hline & $20-30$ & 111 & 80 & 61 & 108 & 80 \\
\hline & $30-40$ & 133 & 109 & 80 & 126 & 102 \\
\hline & $40-50$ & 138 & 109 & 75 & 116 & 118 \\
\hline \multirow{5}{*}{ B } & $0-10$ & 100 & 100 & 100 & 100 & 100 \\
\hline & $10-20$ & 87 & 84 & 92 & 78 & 88 \\
\hline & $20-30$ & 101 & 80 & 94 & 92 & 80 \\
\hline & $30-40$ & 99 & 85 & 76 & 93 & 106 \\
\hline & $40-50$ & 106 & 88 & 111 & 62 & 146 \\
\hline \multirow{5}{*}{$\mathrm{C}$} & $0-10$ & 100 & 100 & 100 & 100 & 100 \\
\hline & $10-20$ & 97 & 94 & 88 & 99 & 102 \\
\hline & $20-30$ & 102 & 94 & 81 & 82 & 79 \\
\hline & $30-40$ & 101 & 121 & 83 & 88 & 87 \\
\hline & $40-50$ & 105 & 110 & 86 & 72 & 123 \\
\hline
\end{tabular}

bonds. The authors found more of the abovementioned fractions in the layer of $15-60 \mathrm{~cm}$ than in $0-15 \mathrm{~cm}$. In addition, they documented that approximately $40 \%$ of the applied $\mathrm{Cu}$ was leached down the soil profile, below $60 \mathrm{~cm}$. According to Pietrzak and McPhail [5], who

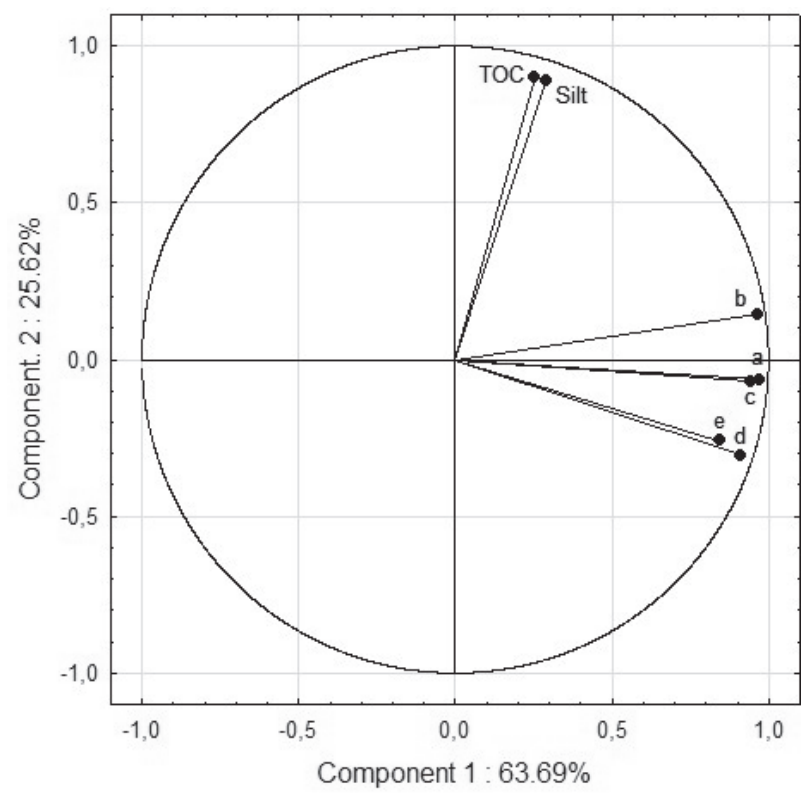

Fig. 2. Results of PCA for $\mathrm{Cu}$ in soil layers and soil factors; a-e soil layers: a $0-10 \mathrm{~cm}, \mathrm{~b} 10-20 \mathrm{~cm}, \mathrm{c} 20-30 \mathrm{~cm}, \mathrm{~d} 30-40 \mathrm{~cm}$, and e $40-50 \mathrm{~cm}$. studied soil in vineyards after fungicide applications, the transformation between the $\mathrm{Cu}$ fractions is very slow, so $\mathrm{Cu}$ can be active in soil for a long time, which can cause its leaching and relocation to the deeper soil layers and into water.

In our study, $\mathrm{Cu}_{1}-\mathrm{Cu}_{3}$ doses did not cause $\mathrm{Cu}$ to translocate below $40 \mathrm{~cm}$ in soils $\mathrm{B}$ and $\mathrm{C}$. Only the $\mathrm{Cu}_{4}$ dose resulted in a significant $\mathrm{Cu}$ transport below this level. In soil $\mathrm{A}$, however, already $\mathrm{Cu}_{3}$ dose caused the translocation of this element down into the soil profile, below $30 \mathrm{~cm}$. This was due to a different texture and content of $\mathrm{C}$ org in soil A than in soils B and C.

\section{PCA Analysis of Data}

We used PCA to point out both soils and $\mathrm{Cu}$ doses of similar vertical $\mathrm{Cu}$ distribution in the soil profile. As the original variables, we used $\mathrm{Cu}$ concentration in each soil layer, TOC, and silt. The $\mathrm{pH}$ of soils was not taken into account because it was not diversified, and therefore it was assumed that this parameter had no effect on $\mathrm{Cu}$ variability in the soil. $\mathrm{Cu}_{0}-\mathrm{Cu}_{4}$ treatments on each soil were assumed as individual cases. Two principal components that explained data variability in $89.3 \%$ were established (Fig. 2). The first principal component (63.69\% of variability) represented the $\mathrm{Cu}$ concentration in soil layers, whereas the highest impact on this component was exerted by layers a $(0-10 \mathrm{~cm})$ and $\mathrm{c}$ $(20-30 \mathrm{~cm})$, which were additionally highly correlated with each other.

Layers d (30-40 cm) and e (40-50 cm) were also highly correlated with each other, but had a lower effect on the principal component than layers a and c. The second principal component $(25.62 \%$ of variability) represented TOC and silt, which were highly correlated with each other.

The cases projection of the plane of the two principal components allowed us to assess similarities and differences between them in terms of $\mathrm{Cu}$ distribution in the soil profile (Fig. 3).

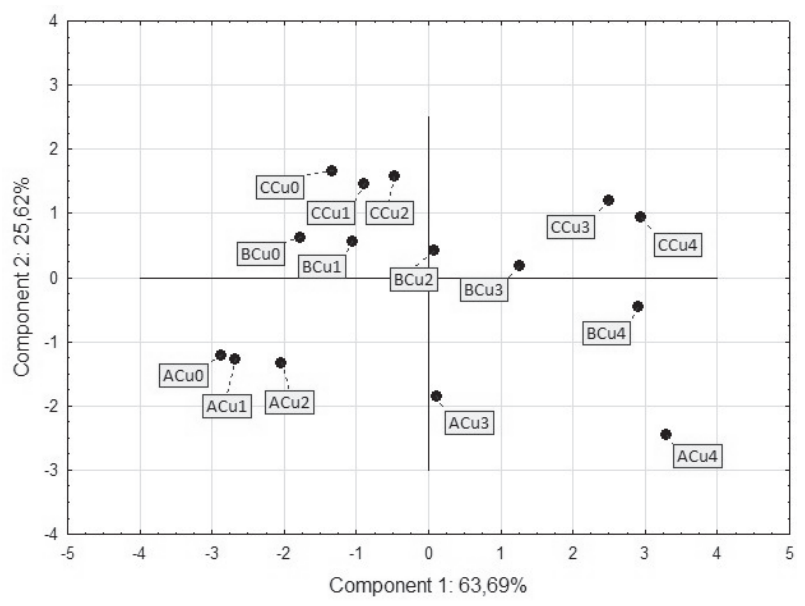

Fig 3. Results of PCA-projection of cases ( $\mathrm{Cu}$ in soil related to type of soil and $\mathrm{Cu}$ dose) on the principal components plane. 
We found that soil $\mathrm{A}$ in general was different in terms of the vertical transport of $\mathrm{Cu}$ in the soil profile from soils $\mathrm{B}$ and $\mathrm{C}$, which were similar to each other. At the same time, a very similar distribution of $\mathrm{Cu}$ in 5 years after its application was found for $\mathrm{Cu}_{0}, \mathrm{Cu}_{1}$, and $\mathrm{Cu}_{2}$. On the other hand, $\mathrm{Cu}_{3}$ and $\mathrm{Cu}_{4}$ had a significantly different distribution pattern than $\mathrm{Cu}_{0}-\mathrm{Cu}_{2}$. These doses were characterized by a similar distribution of $\mathrm{Cu}$ in soil $\mathrm{C}$ while being different in other soils, especially in soil A.

\section{Conclusions}

1) A soil fertilization with $\mathrm{Cu}$ at doses of $4-16 \mathrm{~kg} \mathrm{ha}^{-1}$ in 5 years after the application increased the amount of $\mathrm{Cu}$ in the soil profile to a depth of $50 \mathrm{~cm}$ from the natural amount (6.2-8.6 $\left.\mathrm{mg} \mathrm{kg}^{-1}\right)$ to $14.4-15.7 \mathrm{mg} \mathrm{kg}^{-1}$ after applying the highest dose of this element.

2) Fertilization with the doses of 4-16 $\mathrm{kg} \mathrm{ha}^{-1}$ did not exceed the admissible limit of $\mathrm{Cu}$ concentration for the arable layer in any of the tested soil layers down to a depth of $50 \mathrm{~cm}$.

3) After 5 years from $\mathrm{Cu}$ application, uneven $\mathrm{Cu}$ distribution was observed in the soil profile down to $50 \mathrm{~cm}$. In general, the $\mathrm{Cu}$ concentration decreased in the subsurface layers $(10-30 \mathrm{~cm})$ and increased in deeper layers $(30-50 \mathrm{~cm})$ in relation to the surface layer $(0-10 \mathrm{~cm})$.

4) Based on the $\mathrm{Cu}$ distribution in the soil profile, it can be assumed that $\mathrm{Cu}$ doses up to $8 \mathrm{~kg} \mathrm{ha}^{-1}$, irrespective of soil type, do not pose a risk to the environment in relation to $\mathrm{Cu}$ translocation to deeper soil layers and groundwater.

5) The maximum dose of $\mathrm{Cu}$ that can be applied once every five years is $8 \mathrm{~kg} \mathrm{ha}^{-1}$ for sandy soil with a low content of organic matter and $12 \mathrm{~kg} \mathrm{ha}^{-1}$ for sandy loam.

\section{References}

1. KARAMANOS R.E., GOH T.B. Effect of rate of $\mathrm{Cu}$ application on yield of hard red spring wheat. Comm. Soil Sci. Plant Anal. 35 (13-14), 2037, 2004.

2. KORZENIOWSKA J. Comparison of different winter wheat cultivars with respect to their $\mathrm{Cu}$ fertilization demand. Zeszyty Problemowe Postępów Nauk Rolniczych 541, 255, 2009.

3. KORZENIOWSKA J., STANISLAWSKA-GLUBIAK E., KANTEK K., LIPINSKI W., GAJ R. Micronutrient status of winter wheat in Poland. Journal of Central European Agriculture 16 (1), 54, 2015.

4. STANISLAWSKA-GLUBIAK E., KORZENIOWSKA J. Rules of fertilizing crops with micronutrients [Zasady nawożenia mikroelementami roślin uprawnych]. Studia i Raporty IUNG-PIB, 8, 99, 2007 [Iin Polish].

5. PIETRZAK U, MCPHAIL D.C. $\mathrm{Cu}$ accumulation, distribution and fractionation in vineyard soils of Victoria, Australia. Geoderma. 122, 151, 2004.
6. BESNARD E., CHENU C., ROBERT M. Influence of organic amendments on $\mathrm{Cu}$ distribution among particlesize and density fractions in Champagne vineyard soils. Environ. Pollut. 112, 329, 2001.

7. SENKONDO Y.H., SEMU E., TACK F.M.G. Vertical Distribution of $\mathrm{Cu}$ in $\mathrm{Cu}$-Contaminated Coffee Fields in Kilimanjaro, Tanzania. Commun. Soil Sci. Plant Anal. 46, 1187, 2015.

8. LI W., ZHANG M., SHU H. Distribution and Fractionation of $\mathrm{Cu}$ in Soils of Apple Orchards. Environ. Sci. Pollut. Res. 12 (3), 168, 2005.

9. XIAORONG W., MINGDE H., MINGAN S. Cu fertilizer effects on $\mathrm{Cu}$ distribution and vertical transport in soils. Geoderma. 138, 213, 2007.

10. CUSKE M., KARCZEWSKA A., GAŁKA B., DRADACH A. Some adverse effects of soil amendment with organic Materials - The case of soils polluted by $\mathrm{Cu}$ industry phytostabilized with red fescue. Int. J. Phytoremediation. $18(8), 839,2016$.

11. KABATA-PENDIAS A., MUKHERJEE A.B. Trace elements from soil to human. Springer-Verlag Berlin Heidelberg, 2007.

12. MCLAREN R.G., CLUCAS L.M., TAYLOR M.D., HENDRY T. Leaching of macronutrients and metals from undisturbed soils treated with metalspiked sewage sludge 2 . Leaching of metals. Austr. J. Soil Res. 42, 459, 2004.

13. CUSKE M., KARCZEWSKA A., GAŁKA B. Speciation of $\mathrm{Cu}, \mathrm{Zn}$, and $\mathrm{Pb}$ in soil solutions extracted from strongly polluted soils treated with organic materials. Pol. J. Environ. Stud. 26 (2), 567, 2017.

14. KARCZEWSKA A. Soil protection and recultivation of degraded land [Ochrona gleb i rekultywacja trenów zdegradowanych]. Wydawnictwo Uniwersytetu Przyrodniczego we Wrocławiu, 2012 [In Polish].

15. KORZENIOWSKA J., STANISŁAWSKA-GLUBIAK E. A comparison of the suitability of several methods to estimate the bioavailability of elements in soils to plants. Fresen. Environ. Bull. 22 (4), 943, 2013.

16. KORZENIOWSKA J., STANISŁAWSKA-GLUBIAK E. Comparison of $1 \mathrm{M} \mathrm{HCl}$ and Mehlich 3 for Assessment of the Micronutrient Status of Polish Soils in the Context of Winter Wheat Nutritional Demands. Commun Soil Sci Plant Anal, 46, 1263, 2015.

17. KORZENIOWSKA J., STANISLAWSKA-GLUBIAK E. Proposal of new convenient extractant for assessing phytoavailability of heavy metals in contaminated sandy soil. Environ. Sci. Pollut. Res. 24 (17), 14857, 2017.

18. Dutch Ministry of Infrastructure and the Environment. Soil Remediation Circular 2013, version of 1 July 2013. http://rwsenvironment.eu/subjects/soil/legislation-and/soilremediation

19. Regulation of the Minister of the Environment of 1 September 2016 on the conduct of the assessment of contamination of the surface of the earth (Journal of Laws, item 1395)

20. BEHBAHANINIA A., MIRBAGHERI S.A., NOURI J. Effects of sludge from wastewater treatment plants on heavy metals transport to soils and groundwater. Iranian J. Environ. Health Sci. Eng. 7 (5), 401, 2010.

21. RICHARDS B.K, STEENHUIS T.S., PEVERLY J.H., MCBRIDE M.B. Effect of sludge-processing mode, soil texture and soil $\mathrm{pH}$ on metal mobility in undisturbed soil columns under accelerated loading. Environ. Pollut. 109, 327, 2000.

22. YEGANEH M., AFYUNIM., KHOSHGOFTARMANESH A.H., REZAEINEJAD Y., SCHULIN R. Transport of zinc, 
$\mathrm{Cu}$, and lead in a sewage sludge amended calcareous soil. Soil Use Manage. 26, 176, 2010

23. GEORGIEV P., GROUDEV S., SPASOVA I., NICOLOVA

M. Transport of radionuclides and heavy metals during the cleanup of a polluted cinnamonic soil. J. Geochem. Explor. 174, 148, 2017.

24. KABALA C., SINGH B.R. Fractionation and mobility of $\mathrm{Cu}$, lead, and zinc in soil profiles in the vicinity of a $\mathrm{Cu}$ smelter. J. Environ. Qual. 30, 485, 2001.

25. LI F., FAN Z., XIAO P., OH K., MA X., HOU W. Contamination, chemical speciation and vertical distribution of heavy metals in soils of an old and large industrial zone in Northeast China. Environ Geol 57, 1815, 2009.
26. KABAŁA C. (ed.). 2015. Soils of Lower Silesia: origins, diversity and protection. PTG, PTSH. Wrocław, 2015.

27. KABATA-PENDIAS A., MOTOWICKA-TERELAK T., PIOTROWSKA M., TERELAK H., WITEK T. Assessment of contamination level of soil and plants with heavy metals and sulphur. Guidelines for Agriculture, IUNG Pulawy Publisher, P(53), 1, 1993 [In Polish].

28. FUJIKAWA Y., FUKUI M., KUDO A. Vertical distributions of trace metals in natural soil horizons from Japan. Part 1. Effect of soil types. Water Air Soil Poll. 124, 1, 2000.

29. ANTONKIEWICZ J., PELKA R. fractions of heavy metals in soil after the application of municipal sewage sludge, peat, and furnace ash. Soil Sci. Ann. 65 (3), 118, 2014. 
